\title{
A Critical Discourse Analysis of the Representation of Iraq in Media Discourse (Newspaper Headlines)
}

\author{
Hayder Tuama Jasim Al-Saedi \\ University of Misan, College of Basic Education, Department of English \\ Maysan, Iraq \\ Hayder tuama@uomisan.edu.iq
}

DOI: http://doi.org/10.36892/ijlls.v2i2.307

\begin{tabular}{ll}
$\begin{array}{l}\text { Received: } \\
\text { 10/05/2020 }\end{array}$ & Abstract \\
& The current study aims to investigate the representation of Iraq in newspapers \\
\hline Accepted: & headlines. It investigates how the newspapers headlines had covered the Iraq \\
29/05/2020 & - ISIS conflict. 48 headlines (data collection) were collected from two \\
& different newspapers; twenty-four headlines from an Iraqi newspaper Alsabah \\
& Newspaper and twenty-four headlines from an international newspaper Al- \\
Keywords: & Quds Al-Arabi Newspaper. The data were sampled and analyzed using the \\
Critical discourse & Ideological Square which was proposed by van Dijk (1998, 2006). The \\
analysis; & findings revealed that the sampled headlines of these two newspapers show \\
Underlying ideology; & different underlying ideologies in addressing the Iraq - ISIS conflict. It \\
Ideological square; & concluded that the headlines of every newspaper expressed their ideologies in \\
Iraq; & a positive representation (US) and a negative representation (Them). \\
ISIS &
\end{tabular}

\section{INTRODUCTION}

Having ideologies may represent negative beliefs. Therefore, when we talk about someone who has ideologies, it may refer to him or her negatively. van Dijk (2006) reveals that the negative ideologies belong back to the era of Marx-Engels who considered ideologies as 'false consciousness' form. This negative impression of ideology extended to the 20th century to appear in politics and social sciences. However, Freeden (1996) states that ideologies originally used to refer to a new field to study ideas ideolgie which was introduced by the French philosopher Destutt de Tracy. Therefore, van Dijk defines ideology as the basis of the social representations which can be shared by a social group, they may be positively or negatively (or not) valued depending on a person's perspective, membership of a group or ethics.

van Dijk (1998) claims that ideologies are cognitive and social properties. They are cognitive since they are social beliefs stored in the long term memory and they are not personal or individual ideologies. They are social representations of a social group. They represent a group knowledge and social attitudes, and they may be represented either positively or negatively depending on the person's perspectives, values, and membership of a social group. Ideologies are also acquired individually for many years and reproduced socially by the social practices in general and the group discourses in particular. This makes ideologies relate to the social competitions, conflicts, and so on. For this reason, they are polarized in discourse between Us and Them. Consequently, he (ibid) proposes the ideological square, which is the focus of this study, in which ideologies can be revealed by knowing the positive and negative representation of an event to state the underlying ideologies between Us and Them.

Iraq news were represented differently in press. After the occupation of ISIS to Iraqi cities such as Mosul, Ramadi, and Tikrit, different media discourses especially newspapers 
dealt with this news broadly and became trend and breaking news in news channels at that time. Also, it became good material for the editors to form the headlines of newspapers. Some news agencies and newspapers, Iraqi and international ones, represented Iraq in news as crisis because most of the Iraqi cities became under the domination of ISIS militants. The language of media (newspapers) used different representations of Iraq news; these representations were polarized. They were expressed positively on one hand and negatively on the other hand especially in the headlines of international newspapers depending on different underlying ideologies of the writers of these newspapers.

\section{AIMS OF THE STUDY}

This study aims to investigate the ideological square in the representation of Iraq news in the language of newspapers headlines. It explores how the language of newspapers covered the crisis in which Iraq had during the domination of ISIS to the Iraqi cities. Deeply, it investigates (de)emphasis of positive and negative representations of Iraq - ISIS conflict in the headlines of two newspapers; an Iraqi newspaper Alsabah Newspaper and an international newspaper Al-Quds Al-Arabi Newspaper, and how they represent their underlying ideologies in addressing this kind of conflict.

\section{RESEARCH QUESTIONS}

The researcher tries to address the following questions to find suitable answers to build up conclusions for the current study:

1. How was Iraq - ISIS conflict represented in the newspaper headlines using the ideological square?

2. How did the headlines (de)emphasize the positive and negative representations of Iraq - ISIS conflict?

\section{REVIEW OF LITERATURE}

Discourse studies as new cross-discipline has evolved in the mid-1960s in the fields of humanities and social sciences. They took place in the evolution of new interdisciplines in humanities such as semiotics, pragmatics, and so on. They also were inspired by the new evolutions of the social sciences such as anthropology which paid attention to the communicative situations such as the ethnography of speaking. Furthermore, sociology made a deep influence on the discourse studies especially in ethnomethodological studies. Increasingly, the discourse studies were applied in the studies of communication field in general and studies of mass media in particular (van Dijk, 2009).

van Dijk (ibid) lists the tents of discourse studies since they cannot be summarized easily. He states that discourse studies focused not just on formal grammars and abstract sentences, they focus on the natural use of languages by the language users in real social situations that require interaction and communication. Discourses also analyze the structures and strategies of written/ spoken language or communicative situations. In addition, discourse can be described in the local (micro-) and global (macro-) levels of analyses. These analyses are working under one principle which is called sequentiality where each unit in each level can be produced, interpreted, and analyzed based on the analysis of previous interpreted units. Broadly, discourse studies are not limited to the analysis of verbal scopes of a language, but they also focus on paraverbal, non-verbal scopes of a language (intonation, gestures, and so on), and semiotic scope of a language which includes voices, images, and multimodal aspects of a language. Also, mental and context strategies have been focused by the scholars of discourse studies to study and comprehend language in use. Finally, discourse studies have concentrated on studying the social practices where they play an important role on the social reproduction of social groups in general and their knowledge and ideological beliefs in particular. Therefore, the discourse studies shed the light on studying the social issues such as racism, domination, and inequality. Consequently, large social domains such as 
politics, mass communication, etc. consist of discourse genres where they can be studied in their own contexts.

This made discourse studies to be critical. For this reason, it enabled them to appear as a separate discipline to be called Critical Discourse Analysis which is considered as the most common method in studying discourse analysis. van Dijk (2004) states that discourse analysis should be critical.

Critical discourse analysis (CDA) played a role in language analysis. It appeared to analyze different language data. Wodak and Meyer (2001) state that CDA appeared after the development of discourse and text analysis. It is used as critical linguistics (CL). However, CDA is preferred by scholars more than CL. In giving more clarification, Kress (1990; cited in Wodak and Meyer, 2001) states that CDA is a theory of language which is distinctive and a different type of linguistics. van Dijk (2001) defines CDA as a type of discourse analysis which includes studies in social power, dominance, and inequality. They can be discussed by text and talk using context which can be shown in society and politics. He also adds that CDA is a multidisciplinary study. It aims to suggest different perspectives and modes for a theory, analysis, and application. In this case, we can have critical viewpoints in various disciplines such as pragmatics, conversation analysis, rhetoric, stylistics and so on.

The most prominent scholars in CDA are Norman Fairclough, Ruth Wodak, and Teun A. van Dijk. Fairclough suggested his 3 dimensional modal of CDA. Wodak also proposed her approach in CDA which is called the Discourse - Historical Approach (DHA). In the same vein, Fairclough and Wodak (1997) gave a brief summary of the main principles of CDA that can be researched in this field. They claimed that CDA deals with social problems and power relations. Power relations can be practiced discursively. In addition, discourse can be historical and it is one of the fields that focuses on ideology to reveal the ideological interests of language users. In other words, it shows that there is a connection between text and society in which it makes the analysis of discourse interpretative and explanatory. Finally, van Dijk is one of the scholars who are interested in CDA. He $(1988,1991)$ focuses on the use of media discourse to investigate the ideological interests especially in news discourse.

\section{IDEOLOGY}

van Dijk (2009 cited in van Dijk, 1998) summarized the main points of ideology approach and he stated that originally, ideology is considered as a science of ideas which was proposed by Destutt de Tracy in the 18th century. It received as a negative connotation and reflected as false consciousness which was used by Marx and Lenin. Therefore, ideology has been used negatively in the study and applications of the political practices until today. Ideologies are mental representations and can be reproduced by text, talk, and communication although the traditional studies of ideologies did not concentrate on ideologies as discursive and cognitive aspects. However, the new multidisciplinary approach to ideology of van Dijk shows the social cognition with discourse to express and reproduce ideologies, and its social functions as social groups and relations. For this reason, van Dijk summarized that ideology should not be defined negatively since it is not used to refer to the power abuse. It may refer to other things such as resistance as in the case of socialism, feminism, and pacifism.

van Dijk (2009) also added that ideologies are axiomatic beliefs to show the underlying social representations which are shared by a social group, feature the essential norms and values such as equality, freedom, justice, etc. They can be either used or abused in every social group to assume, defend or struggle their own interests. In addition, ideologies may express the self-image of a group positively or negatively. This feature is called polarization where it shows the positive social representation of US (in-group) and the negative representation of Them (out-group). This can be represented in the ideologies of media discourse which is defined as the typical news-making actions as well as the relations that relate to the readers, resources, and the actors of news, and state. Furthermore, ideologies 
control the attitudes of groups. For instance, racist attitudes about the social issues such as immigrations, integration, etc. These attitudes are abstract and general. They may or may not be shared by the members of a social group. Those members may apply them to their own viewpoints. Consequently, their viewpoints may be contradictory besides their own experiences. This explains why ideologies are represented by mental models, which are held in someone's episodic memory, since ideologies are affected by personal viewpoints about concrete events. These models are biased where they are considered as the foundation of the ideological discourse. They may affect all levels of this kind of discourse. However, sometimes ideological discourse is not expressed in a direct way to represent the attitudes of a social group about social issues and personal viewpoints but it can be expressed indirectly using context models. They are used to express underlying ideologies of social beliefs be polarized. van Dijk $(2006,2009)$ named it as the "Ideological Square." This term is the focus of the current study. It emphasizes the social representation of US (in-group) positively and the social representation of Them (out-group) negatively. Also, it de-emphasizes the negative representation of US and the positive representation of Them.

All these main ideas that van Dijk tries to focus on are still applicable to different discourses to reveal and show the underlying ideologies and how they are used to serve the political beliefs of the members of a social group. Even interpreting a required discourse may need specific contexts to help language consumers to reveal the ideologies of the text producers. For instance, Wodak and Ludwig (1999) state that the interpretation of a text as a communicative event may be achieved differently by the readers and listeners who depend in their interpretation on the social and personal contexts besides their knowledge background. This is prominent in the discourse of media especially the newspaper discourse.

\section{MEDIA DISCOURSE AND IDEOLOGY}

Media discourse plays a role in supporting and spreading ideologies. This happens by using mediation means indirectly and directly through news reports especially through the language of news (Larana, 1994). Therefore, media is concerned with analyzing the language in a discourse which is used to shed the light on critical topics such as power, dominance, and inequality (van Dijk, 1988). van Dijk (1998) puts a model to interpret the discourse of media. This model is called a socio-cognitive model where a media discourse represents the assumptions of ideologies of news makers. This process depends on cultural, political, and social experience. Also, He focused on newspaper reports. He found out that the important roles of news producers are to develop ethnic relations. In this case, ideology is a social cognitive form which can be shared by social groups using the discourse of news. Media discourse is used as the foundation of social representations and practices of the social group members (Van Dijk, 2005). Therefore, the purpose behind controlling the ideological groups is served through media discourse especially printed media where the political language illustrates the events to support an ideological desire of a social group. Printed media uses different discursive techniques where they are used to be persuasive means to spread particular ideologies to the readers (Philips et al, 2004). According to Reath (1998) printed media is a tool that can be used to (re)produce attitudes. It is not just a way to receive information, but it is the guide to the reader's ideological attitudes. Therefore, Fowler (1991) revealed that news does not reflect only facts for free; however, every spoken or written piece of news bears underlying ideologies.

Media discourse became the most common data in using different approaches in different disciplines to analyze it to get different generalizations about the social representations of social group members. Moreover, the language of newspapers is the most prominent data for the scholars in CDA, and pragmatics. It enabled the scholars who study language to reveal different conclusions of different research papers especially in investigating the newspaper headlines. 


\section{IDEOLOGICAL SQUARE}

van Dijk $(1998,2006)$ used the term 'Ideological Square,' which is the focus of this study to reveal and know the underlying ideologies of a group. It can be applied to all levels of discourses. He put four main principles in which they may be applied to all the structures of discourses to reveal ideologies. These principles emphasize the positive things about Us, emphasize negative things about Them, de-emphasize negative things about Us, and deemphasize positive things about Them. van Dijk (2006) analyzed two speeches in a debate in the British House of Commons to discuss the asylum seekers. van Dijk used the ideological square with the discourse strategies to show the ideologies and how this case was represented politically in a positive and negative way.

Since ideological square is applied to all kinds of discourses, it can be seen in the newspaper media discourse. For instance, van Dijk (1988) stated how some cases in media discourse and how they were represented in media. He mentioned cases such as the assassination of elect - president Bechir Gemayel and the occupation of Israel to Beirut and how these events were represented differently in communist and anticommunist press. The newspapers represented the Israeli forces as "Zionists" which is considered as a negative representation but other newspapers did not consider it this way. The use of the ideological square functions as a way to analyze other cases in the world such as the Iraq - ISIS conflict where the researcher purports to study in this research paper.

\section{RELATED LITERATURE}

Newspaper headlines play a role to give a general idea about what the news report is about in a short line. They grab the reader's attention and let them use their own imagination to get what the editors wanted them to get behind the literal language of headlines.

Different discourse domains have been applied to investigate the language of newspapers especially newspaper headlines. Pragmatically, Al-Saedi \& Jabber (2020) investigated the language of Iraqi local newspapers. They found out that Searle's taxonomy is used in Alsabah Newspaper headlines to focus on national affairs in facing their enemies while they cover the domination of ISIS to the Iraqi lands. Also, critical discourse analysis was applied to newspaper headlines to investigate social practices to reveal ideologies. Ononye (2017) analyzed the inaugural address of president Mohammadu Buhari using van Dijk's theory of CDA and context to show the power relations in the Nigerian newspapers. The researcher found out that contexts have linguistic features which are motivated by the power relations in the Buhari's address. Ulum (2016) investigated the ideologies behind the Syrian crisis (refugees) in the newspaper headlines which were written based on crosscultural viewpoints to reveal different ideologies of the editors in different newspapers. Other studies focused on investigating ideologies in other crises. For instance, investigating the Yemen crisis in the headlines of Iranian, Arabian, and western newspapers using the three dimensional model of Fairclough. The findings revealed that there are different ideological viewpoints in the region and there are secular ideas in the discourse of west which leads to a contradiction in the language of newspapers about the Yemen Crisis (Abdi \& Basarati, 2016). Sajid et al (2019) investigated the political ideologies in Pakistani- English newspapers. They found out that the coverage of the same event in printed media represented in newspapers headlines using different discursive techniques to report the same news by different groups to spread their political desire of ideologies. In investigating the Yemen affairs, Alrefaee et al (2019) studied the relationship between the language and ideology in newspapers headlines using Systematic Functional Linguistics and transitivity analysis by Halliday. Their analysis was to show the hidden ideologies behind the newspaper headlines. To sum up, newspaper headlines have become the most prominent data to investigate the ideologies in the recent research literature.

In the same vein, van Dijk (1995) investigated the news articles in two US newspapers; the New York Times and Washington Post. He found out that there are diverse aspects in 
using semantics in discourse. These semantic aspects are affected by underlying ideologies. He revealed that the use of the ideological square in New York Times shows that Arabs were described as terrorists on one hand, whereas Israelis killing Palestinians were not described in the same way they described Arabs. Also, Washington Post found out that various semantic structures affected the writer's underlying ideologies in the op-ed article about Gadhafi.

Other Studies show underlying ideologies in media discourse to cover events in the world. For instance, Fang (1994 as cited in van Dijk, 2009) investigated the riots and violence in the regions that have relations with China and these relations are either friendly or inimical. These riots were described in media as demonstration, struggle, and protest on one hand, and they were described as clashes or riots on the other hand. These were achieved by using syntactic structures to emphasize or de-emphasize the representation of covering the events such as using the active and passive voice.

\section{METHODOLOGY}

\section{DATA COLLECTION}

The data of this study were collected from two different newspapers. One is a national newspaper called ALSABAH NEWSPAPER and the other is an international newspaper which is called AL-QUDS AL-ARABI NEWSPAPER. The researcher had selected 48 headlines; 24 headlines have been chosen from each newspaper from 2014 to 2017 . These headlines were chosen based on the representation of Iraq news in these two newspapers which have covered the Iraq news during the domination and control of ISIS to the Iraqi lands. Since ISIS controlled most of the lands in Iraq and Syria, and the media discourse covers the war between the ISIS militants, the Iraqis and Syrians, this study is limited to investigate the representation of Iraq news. It focuses on the confrontation of Iraqi forces to the ISIS militants and how language of newspapers addresses the mental processes to show the underlying ideologies. The researcher used the 'Ideological Square' to analyze the headlines of the two newspapers. The headlines were translated from Arabic to English by the researcher with an assistance of Mr. Falah Hussein AlSarri, a translator and researcher in the University of Misan, to revise and translate the headlines. Since the 'Ideological Square' can be used in different levels, the researcher analyzed the sampled headlines using this process to build up the main generalizations for this study.

\section{DATA ANALYSIS}

Talking as group members in terms of using the pronoun 'we,' and positively evaluating what we do and have such as their actions, norms, and values, people of the same group defend their resources and the other things that they are interested in. All these notions can reveal that this kind of talk is habitually ideological (van Dijk, 2006). This kind of talk can be seen in the media discourse especially in the newspapers headlines. This is what the researcher purports to analyze in this research paper by investigating how the selected newspapers addressed the use of such pronoun to show the underlying ideologies of the editors in conveying their ideas to the readers.

The editors of Alsabah Newspaper headlines talk as group members on behalf of the Iraqi representatives of government and people. In term of using personal pronouns, they use the pronouns 'we' and 'our' to show the positive representation of the Iraqi actions, norms, and values in describing the representation of Iraq news during the ISIS domination to the Iraqi lands. This can be seen in the headlines 3, 5, 7, 9, 11, 16, 19, and 21 (See Appendix A). In these headlines, we can see how the editors focused on the positive things of the Iraqi military forces in facing the others (enemies and opponents) who are the ISIS militants. Therefore, the editors use the personal pronouns (we and our) to express pertinence of their fighters to the Iraqi forces such as the military forces and popular mobilization forces which were founded based on Fatwa of the Iraqi high cleric Ali AlSistani to face ISIS after they 
dominated the Iraqi lands. In headlines 5 and 9, the editors use 'we' to express the role of these forces in facing their enemy 'ISIS.' In the same vein, in headlines 3, 7, 11, 16, 19, and 21 , the editors used the pronoun 'our' to attribute the Iraqi forces positively by using expressions such as 'our falcons and our popular mobilization' as in headline 7, 'our heroes' as in headline 19, and 'our lions' as in headline 21. The word 'falcons' used in Alsabah Newspaper headlines to refer to the Iraqi Air Forces. Also, the word 'lions' used figuratively as a simile to refer to members of the Iraqi military forces on the battlefield and more positively to represent these forces, they used the word 'heroes' to refer to the Iraqi forces too. The purpose behind these terms is to tell the readers about strength and courage of the Iraqi forces since these terms express positive representations of their people and things in the Iraqi culture.

Because the strategy of ideological square concentrates on the preferred topics to emphasize our good things and their bad things (van Dijk, 2006), Alsabah Newspaper headlines focus on the humanistic role and performance of the Iraqi military forces and popular mobilization forces to help the people of the liberated cities from ISIS domination. This can be seen in the headlines 2, 10, 11, 16, 18, 20, and 23 (See Appendix A). In these headlines, the concentration is on how the mentioned forces especially the popular mobilization forces helped the habitants; this is obvious in headlines $2,16,18$, and 23 because they state the humanitarian support and treatment for those people who were under the control of ISIS domination. Consequently, what is observed in these headlines is the positive ideological representation of the conflict actors in Alsabah Newspaper to address the world politically on how to defend their notions to face what is said about them in media discourse.

In describing the bad things of others, we find that the editors in the same above headlines concentrate on their opponents'/ enemies' bad things. This is obvious in headline 11 since it describes how ISIS owned a jail for the Iraqi habitants who oppose their beliefs and orders. Also, headline 10 shows that there are conflicts among the ISIS militants themselves and headline 16 describes the role of the forces in saving children from 'the terror of Daesh.' As van Dijk (2006) stated that defending the resources and interests by the speakers of group members usually show their ideological notions and beliefs. Therefore, the editors of Alsabah Newspaper formulated their headlines to defend their beliefs and notions which revealed their ideologies to their readers and the world to support the role of the Iraqi forces, and concentrate on the negative representation of their opponent/ enemy (ISIS). For instance, in headline 19, the editors described the fleeing process of SIS militants to their shelters as 'rats' shelters.' This shows that the editors represented ISIS militants negatively in this headline by using ironic statement which is 'rats' shelter' since it is an understatement used ironically in the Iraqi culture to describe someone in general and ISIS militants in particular. In short, Alsabah Newspaper ideology is to face ISIS in media using a political way in which is not accepted by their enemies who are ISIS militants.

However, the way in which Al-Quds Al-Arabi Newspaper formulated its headlines is different from the Alsabah Newspaper using the ideological square (See Appendix B). It showed different underlying ideologies. Its headlines emphasized the role of the Iraqi military forces by using sectarian expressions which attribute these forces as militias especially the popular mobilization forces as it can be seen in headlines 1, 9, 10, and 14. Headline 1 attributed the confrontation of Iraqi forces to ISIS as 'Shia militias.' In the same vein, headline 9 used the same term to express the numbers of members who were killed in facing ISIS. Moreover, headline 10 used the term 'sectarian militias' to attribute the Iraqi forces and popular mobilization forces, whose forces were founded after the Fatwa call by the religious clerics in Najaf, Iraq. This can be seen in the first part of headline 2 although it is considered as supporting forces for the Iraqi military forces and they work under the orders of the representative of the official military forces in Iraq; it can be seen in Appendix A, headlines 22 and 23. The sectarian terms do not include one part of the Iraqi community, they also 
include the non- Muslim people of Iraq. The editors classified other forces in Iraq as a militia; this can be seen in headline 14 where the editors in Al-Quds Al-Arabi Newspaper attributed the Christian fighters as 'Christian militias' and how they were accused of not allowing Sunnis to return to their village. Headline 18 expressed the Iraqi anger of displacing Christians by ISIS. These two headlines (Headline 14 and 18) show the contradiction on which the editors of Al-Quds Al-Arabi Newspaper formulated their headlines. Consequently, the negative underlying representation in the ideological square of this newspaper shows that the newspaper emphasized the role of the Iraqi forces in facing ISIS negatively as sectarian actors who do their actions according to sectarianism. However, Alsabah Newspaper headlines 18, 22 and 23 (See Appendix A) reply on the sectarian accusations of Al-Quds AlArabi Newspaper to the Iraqi military and popular mobilization forces and how they concentrated on their humanistic role and performance in the liberated Iraqi cities. To sum up, ideologies of Al-Quds Arabi Newspaper are represented in a sectarian way in the formulation of its headlines.

Furthermore, Al-Quds Al-Arabi Newspaper headlines de-emphasized the victories which were achieved by the Iraqi military forces. This can be seen in headlines 12, 13, and 20. In headline 12, the editor mentions the celebration of Iraqis of Mosul victory but he or she reminds the reader of the tragic situation that the people of this city suffer in emigrants' camps. In headline 23 (See Appendix A) in Alsabah Newspaper, the editor mentions the congratulations of the Iraqi representatives to the popular mobilization forces on their victories and ensures of their humanistic role in the liberated lands. In headline 8 (See Appendix B), A-lquds Al-Arabi Newspaper editor mentions a declaration of a leader who working in the popular mobilization forces who claims that Alabadi put veto on their entrance in Tal Afar. The editor tries to mitigate the role of popular mobilization forces since headline 22 and 23 (See Appendix A) describe that these forces are under the control of the Iraqi government and they have a humanistic role in liberating the Iraqi lands from ISIS domination. In addition, in headline 13 (See Appendix B), the editor mitigates the victory of liberating Mosul by mentioning the speech of American experts that the war has not finished against the 'Islamic State.' One of the most prominent things is to de-emphasize the positive representation of the Mosul victory, as in headline 20 (See Appendix B). In this headline, the editor claims that the war of facing ISIS is not the end after regaining Mosul. They used a rhetorical expression, which is the last path in the casket of "State" which expresses the underlying ideologies of this newspaper in attributing 'Mosul Victory.' It tries to downplay the good things that Alsabah Newspaper headlines mentioned as a positive role of the Iraqi military forces as mentioned in all headlines especially headline 17 (See Appendix A) where the editor described the 'Islamic State' as a small or alleged state. Also, instead of using the term the 'Islamic State,' the editor used the acronym 'AlDawa'ash," which means ISIS militants (the researcher will talk about this kind of acronym later in this paper), to describe their state and the bane of their successor ironically.

Again, one of the ways to reveal the positive and negative representation of the underlying ideologies is the way in which the newspapers represented the acronym 'ISIS.' It is used differently in both selected newspapers. In Alsabah Newspaper, the headlines focused on the use of Arabic acronym 'Daesh' to be represented as the negative other representation since we always read, hear or watch in news that ISIS militants always warn the world of not using this acronym. For this reason, the editors of Alsabah Newspaper used it to be a negative representation of the others, opponents, or enemies. Moreover, the editors derived words from this acronym where they use them to underestimate or describe their enemy ironically. For instance, they used 'Daeshi' to mean an ISIS militant as in headline 1 and 13. In addition of using the Arabic acronym of 'Daesh,' as in headlines 6, 8, 9, 16, 18, and 19, morphologically, the editors used the Arabic inflectionals to pluralize the word 'Daeshi,' which as mentioned to refer to an ISIS militant, to be 'AlDwa'ash' as a plural form 'ISIS 
militants,' as in headlines $3,4,7,10,11,12,14,15,17,15,17$, and 21 . Finally, headline 24 shows another formulation of the same acronym; it is 'AlDaeshia.' The way in which editors formulated this term is to mean ISIS is not just invaders or militants; the term refers to ISIS as a belief. In short, the editors of Alsabah Newspaper used these terms as a challenge to emphasize ISIS in a negative representation since they are considered as enemies who invaded their lands.

In contrary, Al-Quds Al-Arabi Newspaper used various terms to express ISIS. Some headlines use the regular Arabic acronym 'Daesh' as in headlines 1,15,16, 17, 18, and 19. In addition, the researcher observed how the editors avoided the use of this acronym in other headlines; the editors used 'Islamic state' and just the word 'State,' as in headlines 4, 5, 6, 7, $9,12,13,21,22,23$ and 24. These terms that are used in these headlines are different from what have been used in the headlines of Alsabah Newspaper, as mentioned above. However, using those terms to represent ISIS Al-Quds AlArabi Newspaper headlines may show underlying ideologies since the editors avoided using the acronym and the other terms that have been mentioned above to use sectarian terms in some headlines that are published in this newspaper. In headlines 3 and 15 (See Appendix B), the editors used 'Sunni fighters' and 'Sunni coalition' to represent ISIS respectively. They are contradictory terms because they refer to ISIS. In other words, it is a kind of an underlying accusations to the Iraqi Sunnis that they are terrorists and the ISIS militants are Sunnis and they are from Iraq, but, in headline 11, the editors state that Iraqi Sunni representatives want the Sunni people from the liberated cities to return to their cities and participate in the parliamentary elections. Consequently, this contradicts the way in which the other headlines are written in this newspaper.

\section{DISCUSSION}

In describing nationalism in news, Wodak et al (1998 cited in van Dijk, 2009) claimed that identity plays a role in nationalist ideologies. Identity is an essential issue and it is associated with the positive features in describing the national belonging to the country by habits, language and culture, national character etc. Therefore, van Dijk stated that nationalist ideologies affect the news and news-making when the news journalists cover an event that is especially about war, terrorist attacks, and international competitions. This kind of ideologies can be polarized on behalf of good things for Us and bad things for Them in describing 'our country' and 'our soldiers' (Adams, 1986; Glasgow University Media Group, 1985; Hutcheson, Domke, Billeaudeaux, \& Garland, 2004; Lewis, 2005; Morrison \& Tumber, 1988; Schechter, 2005; Zelizer \& Allan, 2003 cited in van Dijk 2009). Therefore, we can see that the writers of Alsabah Newspaper headlines express their nationalist ideologies by using their national identity to cover the representation of their country, Iraq, in the language of newspapers. In other words, they use this kind of their ideologies to face the underlying ideologies of other newspapers as in Al-Quds Arabi Newspaper. They use what van Dijk (2006) called the 'National Self-Glorification.' He claimed that it is the praise or positive side for someone's own country and he (2009) revealed that nationalism is connected with the norms and values that appear during the crises and wars. These norms and values are called patriotism and loyalty. This is what the writers of Alsabah Newspaper try convey to the readers in general and the Iraqi readers in particular. Consequently, the headlines in Alsabah Newspaper showed the writers' nationalist ideologies by describing the Iraqi forces as lions and how they work together to support people from the liberated cities. Conversely, Al-Quds Al-Arabi Newspaper headlines showed that there are no nationalist ideologies by describing the same forces that were mentioned as militia. Obviously, they use sectarian terms to talk about the Iraqi people and military forces. In short, the nationalist ideologies of the Iraqi citizen polarized differently in these two newspapers since they range between good and bad representations of Iraq during the domination of ISIS to Iraq.

Alsabah Newspaper headlines express unity and solidarity when ISIS controlled most of the Iraqi cities. A lot of Iraqi fighters took into account the call for confronting ISIS 
militants especially when the Fatwa call was released by the high religious figure in Iraq. It was the reason to found other forces such as the popular mobilization forces to support the Iraqi military forces. In this case, the headlines that the writers covered the news express the unity and solidarity of these forces to liberate the cities from ISIS domination. However, AlQuds Al-Arabi Newspaper headlines considered these forces as sectarian forces. To sum up, the two selected newspapers for this study show that there is a conflict or competition to use the language of newspaper headlines to pass their underlying ideologies.

\section{CONCLUDING REMARKS}

The current study investigated the representation of Iraq in newspaper headlines using the ideological square. The researcher addressed the research questions in this paper and he found out that:

1. Iraq - ISIS conflict was represented differently using the ideological square in the headlines of the selected newspapers.

2. The representation of Iraq - ISIS conflict was polarized. Each newspaper used expressions to emphasize good things to make them belong to a specific social group and vice versa.

3. The headlines revealed the underlying ideologies of each newspaper using different expressions to refer to the same news. Alsabah Newspaper, for instance, used terms such as lion, falcons, etc. as a positive representation to all Iraqi forces as part to express unity, solidarity, and patriotism, but Al-Quds Al-Arabi newspaper headlines used sectarian terms to classify the Iraqi forces and people. Moreover, Alsabah Newspaper used morphological aspects to underestimate their enemy as a negative representation of Them, but this is not seen in Al-Quds Al-Arabi Newspaper where the headlines showed contradictory notions. For example, they used terms 'state' and 'Islamic State' to mitigate the use of acronym 'ISIS' on one hand and 'ISIS' on the other hand. Consequently, the headlines showed two different underlying ideologies in these two newspapers.

For future research, the researcher recommends other scholars to investigate the ideological notions in newspapers headlines that focus on the new political issues about Iraq. Studying the discourse strategies may reveal underlying ideologies - those strategies that were used by van Dijk $(1998,2006)$ - in the media discourse of the Iraqi political issues.

\section{REFERENCES}

Abdi, R., \& Basarati, A. (2016). A critical analysis of the representation of Yemen crisis in ideologically-loaded newspaper headlines. GEMA Online ${ }^{\circledR}$ Journal of Language Studies, 16(3).

Alrefaee, Y., Abdul-Ghafour, A., Alazzany, M. \& Alrefaee, S. (2019). A critical discourse analysis of the selected opposition and state printed media on the representation of southern mobility in Yemen. International Journal of Linguistics, Literature and Translation, 2(2), 135-144.

Al-Saedi, H. T. J., \& Jabber, K. W. (2020). A pragmatic study of newspaper headlines in media discourse: Iraq as a case study. International Journal of Linguistics, Literature and Translation, 3(3), 48-59. 
Fiairclough, N. L. \& Wodak, R. (1997). Critical discourse analysis. In T. A. Van Dijk (ed.) Discourse Studies. A Multidisciplinary Introduction, Vol. 2. Discourse as Social Interaction (pp.258-84). London. Sage.

Fowler, (1991). Language in the news: discourse and ideology in the press. New York: Routledge.

Freeden, M. (1996). Ideologies and political theory. a conceptual approach, Oxford: Clarendon Press.

Larana, E. (1994). New social movements: from ideology to identity. Temple University Press: Philadelphia.

Ononye, C.F. (2017). Language, contexts and power relations in Nigerian newspaper headlines on president Muhammadu Buhari's inaugural address. Journal of English and Literature (UUJEL), XI: $1-17$.

Philips, N., Lawrence, T., \& Hardy, C. (2004). Discourse and institutions. Academy of Management, 29(4), 635-52

Reath, D. (1998). The language of newspapers. New York: Routledge.

Sajid, M. A., Anwar, B., \& Ashraf, M. (2019). Politics, ideology and print media: a cda of newspapers' headlines. Khazar Journal of Humanities and Social Sciences. 22(3). 4459.

Ulum, O. G. (2016). Newspaper ideology: a critical discourse analysis of news headlines on Syrian refugees in published newspapers. Turkish Studies, 11(5), 541-552.

van Dijk, T. A. (1988). News as discourse. Lawrence Earlbaum Associates Publication: New Jersey.

van Dijk, T. A. (1991). The interdisciplinary study of news as discourse. A Handbook of Qualitative Methodologies for Mass Communication Research (Jensen KB, Jankowski: NW Eds). Routledge. pp.331-395.

van Dijk, T. A. (1995). Discourse semantics and ideology. Discourse \& Society, 6(2), $243-$ 289.

van Dijk, T. A. (1998). Ideology: a multidisciplinary approach. London: Sage.

van Dijk, T. A. (2001). Critical Discourse Analysis. The Handbook of Discourse Analysis, $352-371$.

van Dijk, T. A. (2004). From text grammar to critical discourse analysis. a brief academy of autobiography. Barcelona: Universitat Pompeu Fabra.

van Dijk, T. A. (2005). Discourse, ideology, and context. Folia linguistica, 35(1-2), 11-40.

van Dijk, T. A. (2006). Ideology and discourse analysis. Journal of political ideologies, 11(2), 115-140. 
van Dijk, T. A. (2009). News, discourse, and ideology. The Handbook of Journalism Studies. New York: Routledge, 191-204.

Wodak, R. and Ludwig, C. (1999). Challenges in a world changes. Passagen Verlag: Vienna.

Wodak, R. \& Meyer, M. (2001) Methods of critical discourse studies. London: Sage.

APPENDIX (A)

Alsabah Newspaper Headlines

No. Headlines

130 Daeshi leaders are running away from the Right Side.

2 Alhadhar habitants praise the humanistic treatment of the popular mobilization.

3 Our forces destructed tens of 'Aldawa'ash' in Alzanjili

4 The popular mobilization sends tens of "AlDawa'ash" to the hell

5 Joint Operations: we are waging the last meters battle to announce Victory

6 "Daesh" van ishes from the Map

7 Our falcons and Mobilization kill tens of "Aldawa'ash"

8 Alabadi: the rests of "Daesh" besieged in the last spans of the hand

9 Lieutenant Colonel AlAsadi: we are ready to hold down the sinks of "Da'ash"

10 Conflict between "Dawa'ash" of AlHawija and Tala'afir

11 Our forces found a big prison for AlDawa'ash in Mosul

12 Popular mobilization besieged Nainawa desert in fron t of "AlDawa'ash"

13 A handicapped "Daeashi" launches a terrorist attack in Alzanjili

14 Fleeing tens of "AlDawa'ash" from Tala' afir

15 Alabadi: we will never leave a span under the hand of AlDawa'ash

16 Our forces save the children of Mosul from the terror of "Daeash"

17 The victory of Mosul dissolves the "alleged State of AlDawa'ash" and the death of its leader accelerates its mortality

18 In Mosul a rifle against "Daeash" and a hand helps families

19 "Daeash" restores to rats holes fleeing from our heroes

20 Popular Mobilization is the major sustain to the security forces

21 Our lions defeat $\{$ AlDawa'ash\} in Tala'afir

22 Alabadi: Our forces works under the umbrella of the government

23 Parliament members bless the victories of the Popular Mobilization forces and its human performance

24 'AlDaeshia' not just 'Daesh' 
APPENDIX (B)

Al-Quds Al-Arabi Newspaper Headlines

\begin{tabular}{|cl|}
\hline No. & \multicolumn{1}{c|}{ Headlines } \\
1 & Shia Militias to repel 'Daesh' from Baghdad and fears of sectarian massacres \\
2 & Thousands of Shia responds to Alsistani Fatwa and an Iraqi air strike on Bashmargha \\
3 & Sunni fighters take over Iraqi cities after 'a tactic Withdrawal' \\
4 & Iraqi Sunni bloc calls for ceasefire to 'isolate Islamic State' \\
5 & $\ldots$ and 'State' launches the most violent attack on 'Popular mobilization forces' \\
6 & Iraq is between two wars: 'Islamic State' and kidnapping militias \\
7 & 'Popular mobilization forces' lose a leader and a number of member in suicide bombing in clashes \\
8 & with 'Islamic State' \\
9 & 17 of Shia militias killed in clashes with 'Islamic State' in Diyala \\
10 & The sectarian militias invade Iraq cities \\
11 & Iraq Sunnis stipulate to return the displaced people to their regions to participate in the local and \\
12 & parliamentary elections \\
13 & Amesul celebrates the victory on 'Islamic State' and most of its habitants in refugees camps \\
14 & Christian Militias are accused not allowing the Sunni habitants to enter Alhamdania region. \\
15 & Continuing the fall of Iraqi cities by 'Sunni Coalition' led by 'Daesh' and the regular military \\
16 & collapses \\
17 & 'Dhe ghost of 'Daesh' hangs over Iraq \\
18 & Iraqi anger of abandoning Christians from Mosul by 'Daesh' \\
19 & 'Daesh' kills 6 and kidnaps 14 others in Baqubah \\
20 & Regaining Mosul is not the last path in the casket of 'State' \\
21 & Fighters of 'State' refuse surrender in the last positions west Mosul \\
22 & Fights between the Iraqi forces and 'Islamic State' in the old Mosul \\
23 & 'State' intensifies its suicide attacks in Mosul in the middle of fierce street war \\
24 & Attacks of 'Islamic State' in Mosul, Kirkuk, and Alanbar. \\
\hline
\end{tabular}

\section{AUTHOR'S BIO:}

Hayder Tuama Jasim Al-Saedi is an instructor in the University of Misan/ college of Basic Education/Department of English. He holds a Master's degree in Applied Linguistics from Southern Illinois University at Carbondale. His research interests are in Pragmatics, Critical discourse analysis, Phonetics and phonology. 